\title{
INVESTIGATION OF THE PHYSICAL-MECHANICAL PROPERTIES OF TIMBER USING ULTRASOUND EXAMINATION
}

\author{
Marko Teder ${ }^{1}$, Kalle Pilt ${ }^{2}$, Matis Miljan ${ }^{3}$, Vello Pallav ${ }^{4}$, Jaan Miljan $^{5}$ \\ Institute of Forestry and Rural Engineering, Estonian University of Life Sciences, \\ Kreutzwaldi 5, Tartu 51014, Estonia \\ E-mails: ${ }^{1}$ marko.teder@emu.ee (corresponding author); ${ }^{2}$ kalle.pilt@emu.ee; \\ 3matis.miljan@emu.ee; ${ }^{4}$ vello.pallav@emu.ee; ${ }^{5}$ jaan.miljan@emu.ee \\ Received 07 Oct. 2010; accepted 20 Apr. 2012
}

\begin{abstract}
This research uses a non-destructive method - ultrasound - to examine timber, combining the results of measurement with the properties of strength and stiffness. The purpose of this work is to explore the possibilities of grading wood structure in situ using ultrasound measurements, specifically, the moisture content and density of the timber. The timber used in these experiments was taken from existing buildings of different ages. The potential of replacing direct measurements with indirect measurements by ultrasound was also investigated. The physical-mechanical properties of wood were determined in laboratory conditions according to standard practices, and the method of non-destructive measurements was based on a commercial test device based on $54 \mathrm{kHz}$ compressional wave $50 \mathrm{~mm}$ diameter ultrasound transducers. Direct measurements were performed in the longitudinal and radial material directions. Indirect measurements were performed with transducers positioned on the same lateral surface of the sample. A weak correlation was found within the different measurements. Longitudinal measurements characterise bending strength with $\mathrm{R}^{2}=0.18$ and modulus of elasticity with $\mathrm{R}^{2}=0.37$. In multiple regression analysis, stronger correlations were found; prediction equations of bending strength and modulus of elasticity were found with $\mathrm{R}^{2}=0.40$ and $\mathrm{R}^{2}=0.81$, respectively.
\end{abstract}

Keywords: acoustic measurement, bending strength, modulus of elasticity, density, moisture content, speed of sound, direct and indirect methods.

\section{Introduction}

When renovating buildings it is necessary to assess the physical condition and strength of timber structures. The most accurate way of determining the mechanical properties is by destructive methods, the most relevant results being usually obtained from compression, tension and bending tests. However, there are situations where the wood structures need to be evaluated in situ, where the timber cannot be removed or sampled destructively and where visual assessment is constrained, since the timber structural member may have one or several sides covered and/or its position or geometry does not enable an inspection. At this point non-destructive methods are a possible alternative. There are several non-destructive methods that can be used in the assessment and determination of properties of timber, such as mechanical loading, electrical resistance measurement and acoustic, thermal and electromagnetic wave propagation (Niemz 2009).

Sound and ultrasound have been used rather widely. In general terms sound consists of an elastic wave that propagates through a material, its behaviour being different in various materials or in different conditions within the same type of material. Consequently a correlation between the speed of sound and certain properties of a material such as stiffness can be made (Lempriere 2002; Kettunen 2006).
In the evaluation of timber properties ultrasound is a widely used method in sawmills, where the longitudinal measuring method has been used to sort lumber into various strength classes. Obstacles occur if there is need to assess wood structures in situ, because in most cases both ends of a beam or joist, for example, are covered and the measurement cannot be made. This is because measurement can only be carried out when placing the transducers parallelly on one side or across the detail facing each other. But the latter way of measuring is not always possible, because of the inaccessibility of both sides. This kind of measurement method also only provides the local properties of wood. The main advantage of using ultrasound is that the piece being measured will not be damaged in any way and it can continue to be used as no deformations occur. Tests can be made on the same member repeatedly without any substantial variation in results (Bucur 2006).

Ultrasound wave propagation is directly related to the elastic properties of the material through which it propagates. If wood is damaged, its stiffness is likely to decrease. Sound wave speed is a function of the square root of material stiffness. Lower speed or longer propagation times are generally indicative of poorer conditions in a sample. It is assumed that ultrasound pulse velocity can be used as an index of wood quality of as it can detect defects like cracks, knots, decay, and deviation in grain 
orientation. In spite of the non-homogeneous nature and anisotropy of wood, it is possible to correlate the efficiency of the propagation of a sound wave with physical and mechanical properties (Drdácký, Kloiber 2006).

The density and modulus of elasticity also affect the acoustic properties of wood. Bucur and Chivers (1991) observed that in conditions of increased density the speed of sound decreased. Thus, the propagation of sound varies in timber from different species of tree. In other investigations the results have shown that velocity increases for large density values (Haines et al. 1996). By contrast, Mishiro (1996) found that velocity was not affected by density. As wood is an anisotropic material, the speed of sound also varies in different directions due to cell structure (Kettunen 2006). Transverse waves are scattered by each cell wall, while the longitudinal orientation of wood cells and their slenderness ratio facilitate ultrasound propagation. The greater number of impacts of waves on wood cells in the transverse direction slows them down (Kotlinova et al. 2008). Moreover, ultrasound propagation paths in directions differing from the main orthotropy axes (longitudinal $\mathrm{L}$, radial $\mathrm{R}$ and tangential $\mathrm{T}$ ) are significantly shifted from a straight line between the transducers, the actual trajectory being dependent on the local ring and grain angles (Sanabria et al. 2011). Ultrasound velocity is influenced by width of annual rings only in the radial direction, due to the macroscopic structure of wood, the relative proportions of early and latewood and the cell orientation in the growth ring (Drdácký, Kloiber 2006). Ultrasound velocity decreases with increasing moisture content (Drdácký, Kloiber 2006). The velocity also decreases dramatically with moisture content up to the fibre saturation point, and thereafter the variation is very small (Bucur 2006). It is also notable that moisture content above the fibre saturation point does not have any significant effect on ultrasound velocity when measured in the longitudinal direction (Sakai et al. 1990; Oliveira et al. 2005).

Overall the direct longitudinal measurement is fairly reliable in the assessment of the wood strength. However, according to Machado et al. (2009) it is necessary to note that an indirect measurement can provide quite good results. Furthermore the results seem to indicate that as the distance $(10$ to $40 \mathrm{~cm})$ between the transducers becomes greater the influence of deeper wood layers in the velocity of wave propagation increases. Most of the signal energy is transmitted to the back-wall of the test piece while only a small part of the energy is transmitted along the edge surface. For wood measurement the most favourable frequency range is between $20 \mathrm{kHz}$ and $500 \mathrm{kHz}$ because of the high attenuation of ultrasonic waves in wood at higher frequencies (ASTM 494-89 1989; Tanasoiu et al. 2002). The length of the piece has more influence on the velocity than the cross-sectional area (Arriaga et al. 2006). The longitudinal measurement is strongly and continuously affected by the width $(b)$ over thickness $(h)$ ratio of the specimen. Largest velocities are obtained when the ratio lies between one and two, and the specimen is a rod, and $b$ and $h$ are greater than the wavelength (Bucur 2006).
The present study aimed to test the relationships between ultrasound velocity, modulus of elasticity and bending strength while also taking into account variations in moisture content and density. Ultrasound velocity, wood density and moisture content were used as independent variables and bending strength and modulus of elasticity were the dependent variables. The aim was to see if the latter characteristics could be predicted via the first.

\section{Methods}

The experiments were carried out in a laboratory at 21$23{ }^{\circ} \mathrm{C}$ and $20-40 \%$ relative humidity. 25 logs and beams of Picea abies taken from buildings with various uses and of different ages were used in the research. 92 pieces with dimensions of $50 \times 50 \times 1005-1100 \mathrm{~mm}^{3}$ were sawn from the collected material. The chosen dimensions were based on the standard EN 408:2005 (2005), which specifies that the length of the piece for the bending test should be at least 19 times the height of the cross-section.

First of all, four different types of measurement with a TICO Ultrasound Instrument fitted with $50 \mathrm{~mm} 54 \mathrm{kHz}$ compressional wave transducers were conducted (Fig. 1):

1) Five times with a spacing (transmitter-receiver distance) of $200 \mathrm{~mm}$ on the tangential surface at early wood positions using the indirect method (variant A);

2) Three times with a spacing of $600 \mathrm{~mm}$ on the tangential surface at early wood positions using the indirect method (variant $\mathrm{B}$ );

3) Once between the end surfaces in the longitudinal direction (variant $\mathrm{C}$ );

4) Five times in the radial direction by random selection in the direct method (variant D).

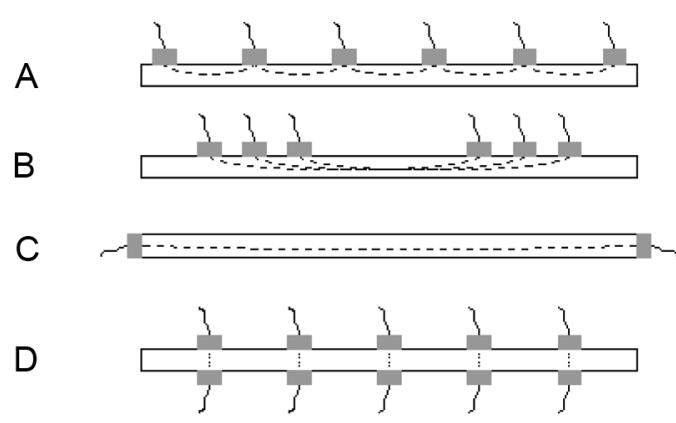

Fig. 1. Diagrams showing each of the measurement methods applied with an ultrasound device: A) five times with a spacing of $200 \mathrm{~mm}$ on the tangential surface at early wood positions using the indirect method; B) Three times with a spacing of $600 \mathrm{~mm}$ on the tangential surface at early wood positions using the indirect method; C) once between the end surfaces in the longitudinal direction; D) five times in the radial direction by random selection in the direct method

The device works by sending an ultrasound wave into the sample by the transmitter probe which is picked up by a receiver probe with the time of flight $t$ recorded in microseconds and it also calculates the velocity $v$ when the distance $d$ is entered, with $v=d / t$. The distances were chosen according to the suggestions of the manual of the 
testing device for the maximum and minimal parameters (Tico User Manual 2008).

Before every test (Fig. 2) the measured length of the sample piece was entered into the device and the corresponding velocity reading in $\mathrm{m} / \mathrm{s}$ was recorded. For better contact between the wood surface and the probes glycerine (propane-1,2,3-triol) was applied thinly onto the probes. This ensured effective transfer of the ultrasound wave between the surface of the sample and the probes. The transducers were equally pressed on the surfaces of the members.

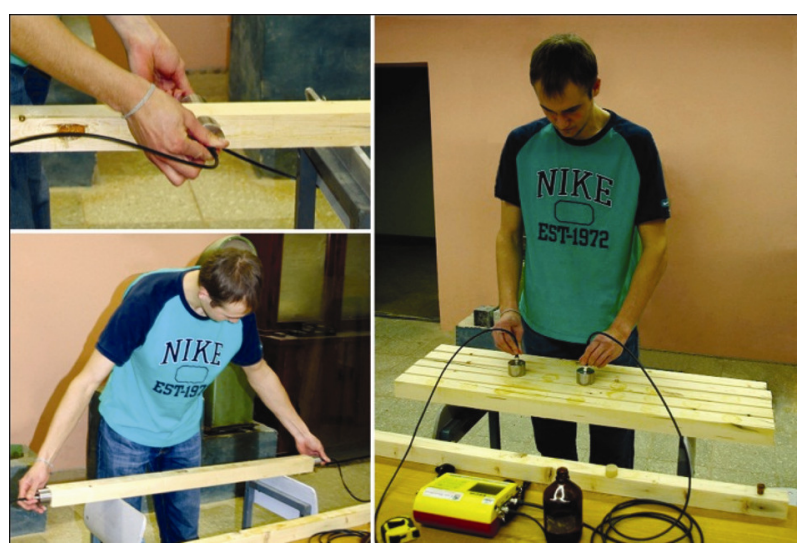

Fig. 2. Conducting tests with a TICO Ultrasound Instrument device and $54 \mathrm{kHz}$ transducers

The bending strength of the test pieces was determined using an Instron 3369 device, based on standard EN 408:2005 (2005). According to this standard the sample was laid across two supports set $1000 \mathrm{~mm}$ apart and thereafter it was loaded with a static force at the centre until it broke. Here it should be noted that the force was applied in the radial direction with younger annual rings facing upwards. With this test the modulus of elasticity as well as the bending strength was measured.

In order to define the moisture content of the samples, test pieces with dimensions of $50 \times 50 \times 30 \mathrm{~mm}^{3}$ were sawn from them. These pieces were weighed on an electronic scale with a readability of $\pm 0.01 \mathrm{~g}$ and afterwards placed into a drying oven at a temperature of $103 \pm 2{ }^{\circ} \mathrm{C}$. The pieces were dried until their differences of weighing at two-hourly intervals were less than $0.1 \%$ (EN 408 : 2005 2005). Moisture content was defined according to ISO 3130:1975 (1975).

For determining the density, pieces with dimensions of $50 \times 50 \times 75 \mathrm{~mm}^{3}$ were sawn from the specimens. These were weighed on the same electronic scale and thickness, width and length were measured with a digital calliper (readability of $\pm 0.01 \mathrm{~m}$ ). The measurements were multiplied (EN 408:2005 2005), and the density of wood was calculated according to ISO 3131: 1975 (1975).

All data processing was conducted by MS Excel, STATISTICA 10 and R software.

\section{Results and discussion}

The variability of density, bending strength and modulus of elasticity were regular and spread out, the variation was not mainly in one or the other end of extreme and was not closely clustered. Consequently, the experimental data was adequate to carry out the regression analysis (Table 1).

Table 1. Characteristics of the statistical indicators

\begin{tabular}{lrrrr}
\hline $\begin{array}{l}\text { Main indicators/ } \\
\text { Characteristics }\end{array}$ & $\begin{array}{c}\text { Max. } \\
\text { bending } \\
\text { strength, } \\
\mathrm{MPa}\end{array}$ & $\begin{array}{c}\text { Modulus } \\
\text { of } \\
\text { elasticity, } \\
\mathrm{MPa}\end{array}$ & $\begin{array}{c}\text { Moisture } \\
\text { content, } \\
\%\end{array}$ & $\begin{array}{c}\text { Density, } \\
\mathrm{kg} / \mathrm{m}^{3}\end{array}$ \\
\hline Mean & 42.98 & 10156.3 & 8.85 & 443.12 \\
Median & 43.36 & 10370.8 & 8.95 & 434.48 \\
$\begin{array}{l}\text { Standard } \\
\text { deviation }\end{array}$ & 13.87 & 2321.5 & 1.76 & 54.01 \\
Minimum & 9.06 & 6317.2 & 5.34 & 329.61 \\
Maximum & 80.12 & 17115.6 & 11.41 & 596.53 \\
\hline
\end{tabular}

It is necessary to ascertain the relationships between the results of direct and indirect measurement methods of investigation by ultrasound. It can be concluded that the greatest velocities were given by method C (between the end surfaces in the longitudinal direction) and the lowest by method D (radial direction in the direct method) (Fig. 3). The general variation and fluctuation of ultrasound velocities using methods $\mathrm{C}$ and $\mathrm{D}$ are lower compared with the results of indirect measurements (methods $\mathrm{A}$ and $\mathrm{B})$.

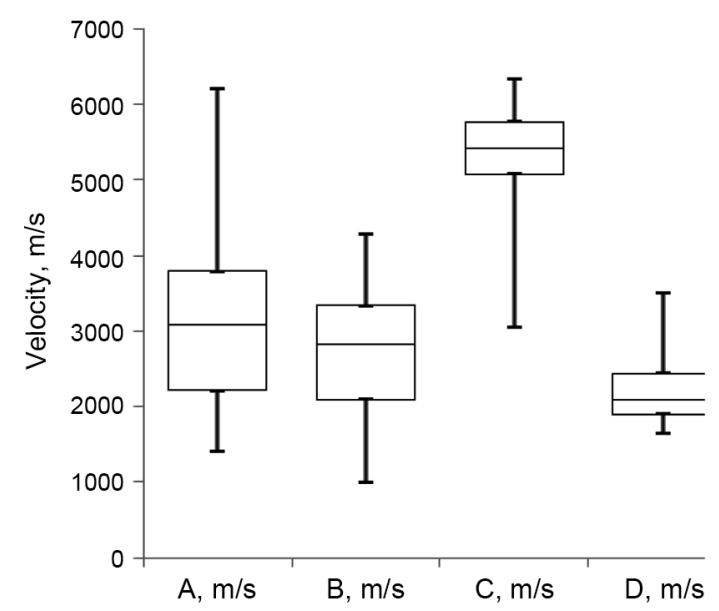

Fig. 3. Box plot charts of ultrasound velocities: A) indirect measuring with a spacing of $200 \mathrm{~mm}$ on the tangential surface; B) indirect measuring with a spacing of $600 \mathrm{~mm}$ on the tangential surface; C) longitudinal direct measuring between the end surfaces in the longitudinal direction; D) transversal direct measuring in the radial direction

Machado et al. (2009) found that the relative difference between direct and indirect measurements of defectfree specimens was $\pm 10 \%$, which shows a good relationship between the results of the different ultrasound measuring methods. Thus, the use of the indirect method on site, where only one side of the wood structure is accessible, is possible. 
The results of methods A and B fluctuate substantially more than $\mathrm{C}$ and $\mathrm{D}$. The smallest fluctuation of the results was obtained with method D.

Table 2 shows the correlation matrix between the individual measured variables. The relationship between maximum bending strength and modulus of elasticity is fairly strong $(r=0.72)$, which shows the latter to be an important factor in assessment of wood structures. There is also a strong relationship between density and modulus of elasticity $(\mathrm{r}=0.8)$, which is about 0.3 higher than between density and maximum bending strength. The fact that stiffness (modulus of elasticity) is a more global property than bending strength, which has been confirmed by Hahnijärvi et al. (2005), is also shown by this research. Thus density can also be a good indicator of wood strength.

Moving on to the analysis of ultrasound velocities, the relationships between direct $(\mathrm{C}$ and $\mathrm{D})$ and indirect measurements (A and $\mathrm{B}$ ) are weak and therefore do not support the substitution of these methods with one another. In summary the results confirm that the shorter the measurement distance, the more localized is the evaluation of the sample.

In analysing the relationships between ultrasound measurements and other characteristics, the fitted relationship is linear and the results of longitudinal measurements characterise the bending strength with $r=0.42$ and the modulus of elasticity with $r=0.61$ (Figs. 4 and 5). According to the results of the indirect measurements (A and B) only method B gives a moderate linear relationship with the modulus of elasticity (Fig. 6), the relationships with other characteristics being weak, except with each other, which is moderate $(r=0.63)$. In investigating the relationships between strength and ultrasound veloci- ties Arriaga et al. (2006) found that a weak correlation between them occurred due to local defects having more influence on strength than the general quality of specimens. In that way the results from this research may be explained. The defects in members have important role in strength, but in situ it is difficult to identify them. This study examined specimens without classifying themselves.

A negative correlation occurs between moisture content and ultrasound velocity (Bucur 2006; Oliveira et al. 2005). In analysing the results of our tests the overall negative correlation was found to be true, especially for the results of the transverse method (D), for which there is a strong negative correlation $(\mathrm{r}=-0.78)$. As the measurement distances become larger the moisture content becomes decreasingly important.

To evaluate the stiffness of wood prediction equations based on specific variables were examined. The variables (x) comprised ultrasound velocities together with density and moisture content, which could be determined without any substantial damage to the wood structure (Table 3). It can be concluded that the best prognosis of the modulus of elasticity is given by density and longitudinal measurement $(\mathrm{C})$, which describe the variety of the modulus of elasticity with $64.3 \%$ and $37.3 \%$, respectively.

Next, all six chosen variables were included to a multiple regression analysis. It turned out that the prediction equation accounts for $81.1 \%$ of the variety of the modulus of elasticity (Table 4). Variables A and D ( $p$-values were greater than 0.05 ) were eliminated one by one, because their influence in multiple regression analysis was not statistically significant.

Table 2. The correlation matrix of characteristics of specimens (Correlation coefficient $r$ )

\begin{tabular}{|c|c|c|c|c|c|c|c|c|}
\hline Characteristic & $\mathrm{A}, \mathrm{m} / \mathrm{s}$ & $\mathrm{B}, \mathrm{m} / \mathrm{s}$ & $\mathrm{C}, \mathrm{m} / \mathrm{s}$ & $\mathrm{D}, \mathrm{m} / \mathrm{s}$ & $\begin{array}{l}\text { Max. bending } \\
\text { strength, MPa }\end{array}$ & $\begin{array}{c}\text { Modulus of } \\
\text { elasticity, } \mathrm{MPa}\end{array}$ & $\begin{array}{l}\text { Moisture } \\
\text { content, \% }\end{array}$ & $\begin{array}{c}\text { Density, } \\
\mathrm{kg} / \mathrm{m}^{3}\end{array}$ \\
\hline $\mathrm{A}, \mathrm{m} / \mathrm{s}$ & 1 & & & & & & & \\
\hline $\mathrm{B}, \mathrm{m} / \mathrm{s}$ & 0.63 & 1 & & & & & & \\
\hline $\mathrm{C}, \mathrm{m} / \mathrm{s}$ & 0.15 & 0.27 & 1 & & & & & \\
\hline $\mathrm{D}, \mathrm{m} / \mathrm{s}$ & 0.32 & 0.05 & -0.12 & 1 & & & & \\
\hline $\begin{array}{l}\text { Max. bending strength, } \\
\mathrm{MPa}\end{array}$ & 0.12 & 0.25 & 0.42 & -0.25 & 1 & & & \\
\hline $\begin{array}{l}\text { Modulus of elasticity, } \\
\qquad \mathrm{MPa}\end{array}$ & 0.11 & 0.31 & 0.61 & -0.38 & 0.72 & 1 & & \\
\hline Moisture content, \% & -0.23 & -0.04 & 0.09 & -0.78 & 0.31 & 0.30 & 1 & \\
\hline Density, $\mathrm{kg} / \mathrm{m}^{3}$ & -0.09 & 0.07 & 0.40 & -0.31 & 0.51 & 0.80 & 0.16 & 1 \\
\hline
\end{tabular}

Notes: figures marked light grey indicate a moderate relationship $(0.3 \leq|\mathrm{r}| \leq 0.7)$; figures marked dark grey indicate a strong relationship ( $|\mathrm{r}| \geq 0.7)$.

Table 3. Predicting modulus of elasticity (y) with different variables (x) individually

\begin{tabular}{llrr}
\hline \multicolumn{1}{c}{ Variable $(\mathrm{x})$} & Regression equation & $\mathrm{R}^{2}$ & $\mathrm{p}$-value \\
\hline $\mathrm{A}, \mathrm{m} / \mathrm{s}$ & $\mathrm{y}=9361.8+0.253^{*} \mathrm{x}$ & 0.012 & 0.301 \\
$\mathrm{~B}, \mathrm{~m} / \mathrm{s}$ & $\mathrm{y}=7845.3+0.848^{*} \mathrm{x}$ & 0.094 & 0.003 \\
$\mathrm{C}, \mathrm{m} / \mathrm{s}$ & $\mathrm{y}=-3735.8+2.576^{*} \mathrm{x}$ & 0.373 & $<0.001$ \\
$\mathrm{D}, \mathrm{m} / \mathrm{s}$ & $\mathrm{y}=14891.5+(-2.152)^{*} \mathrm{x}$ & 0.144 & $<0.001$ \\
Density, $\mathrm{kg} / \mathrm{m}^{3}$ & $\mathrm{y}=-5116.5+34.477^{\mathrm{x}}$ & 0.643 & $<0.001$ \\
Moisture content, \% & $\mathrm{y}=6599.3+401.9 * \mathrm{x}$ & 0.093 & 0.003 \\
\hline
\end{tabular}




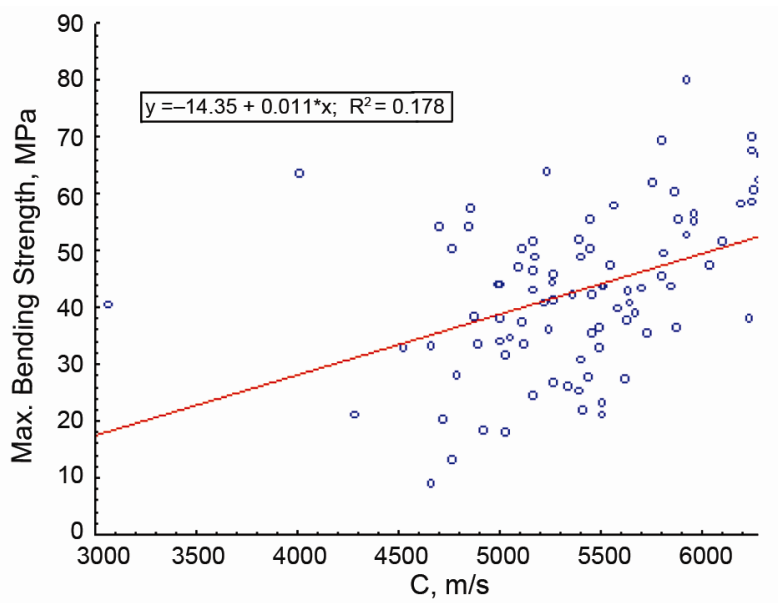

Fig. 4. Relation between max. bending strength and C (longitudinal direct measurement between the end surfaces in the longitudinal direction)

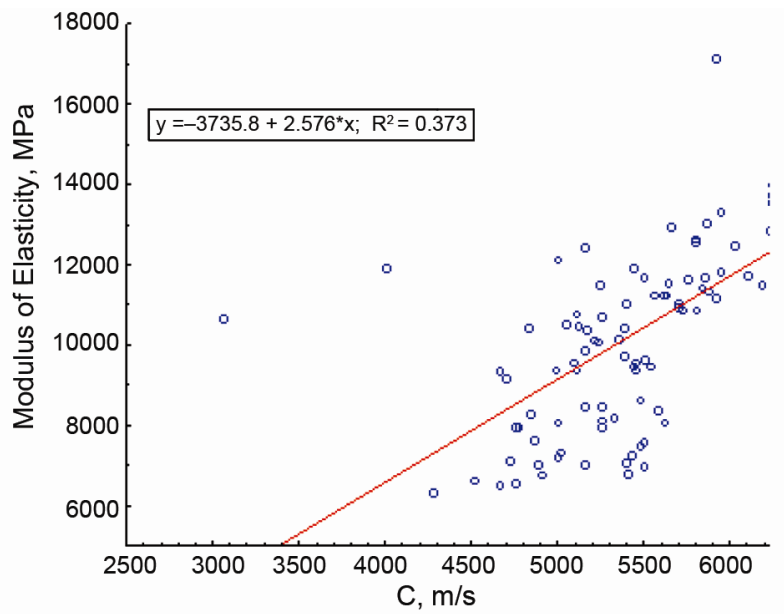

Fig. 5. Relation between modulus of elasticity and C (longitudinal direct measurement between the end surfaces in the longitudinal direction)

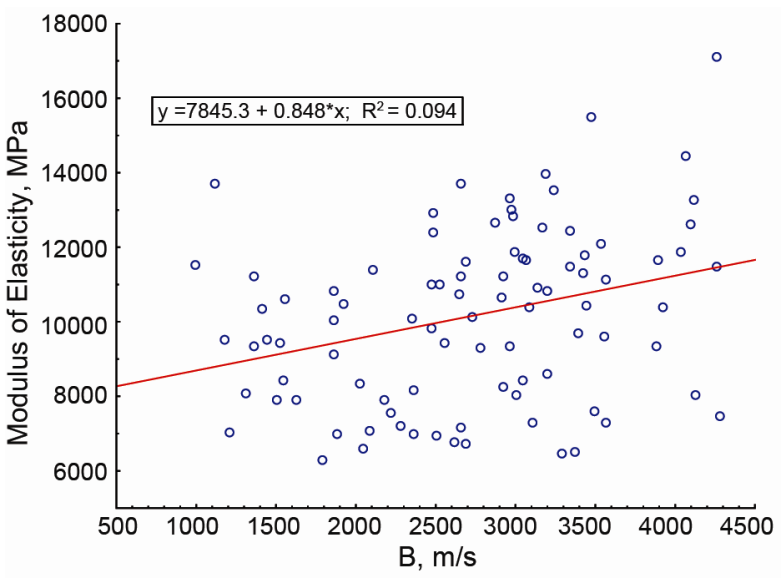

Fig. 6. Relation between modulus of elasticity and B (indirect measurement with a spacing of $600 \mathrm{~mm}$ on the tangential surface)

The analysis resulted in a statistically significant $(p<0.001)$ regression equation with four variables that describes $80.7 \%$ of the variability of the modulus of elasticity $\left(\mathrm{R}^{2}=0.807\right)$ :

$$
E=-12230+0.259 \cdot B+1.213 \cdot C+27.72 \cdot \rho+238.4 \cdot W,(1)
$$

where: $E$ is the modulus of elasticity, $\mathrm{MPa} ; B$ and $C$ are the corresponding measuring techniques, $\mathrm{m} / \mathrm{s} ; \rho$ is density, $\mathrm{kg} / \mathrm{m}^{3} ; W$ is moisture content, $\%$.

Similar data processing was conducted for bending strength, for which regression equations for each variable were first derived. None of the equations predict the bending strength with $|r|>0.3$ (Table 5). Once again, the best correlation by individual regression analysis is obtained with the variables $\mathrm{C}$ and density, which describe the variety of bending strength with $17.8 \%$ and $26.1 \%$, respectively. Within this investigation, again, only variable $\mathrm{A}$ is not statistically significant concerning the relevance of mean values.

Table 4. Predicting modulus of elasticity (y) with multiple variables (x)

\begin{tabular}{lcccc}
\hline & $\begin{array}{c}\text { Regression equation with 6 variables } \\
\left(\mathrm{R}^{2}=0.811\right)\end{array}$ & $\begin{array}{c}\text { Regression equation with } 4 \text { variables } \\
\left(\mathrm{R}^{2}=0.807\right)\end{array}$ \\
\cline { 2 - 5 } \multicolumn{1}{c}{ Variable } & regression - coefficient & p-value & regression - coefficient & $\mathrm{p}$-value \\
\hline $\mathrm{A}, \mathrm{m} / \mathrm{s}$ & 0.205 & 0.178 & - & 0.529 \\
$\mathrm{~B}, \mathrm{~m} / \mathrm{s}$ & 0.384 & 0.029 & 1.213 & 0.0002 \\
$\mathrm{C}, \mathrm{m} / \mathrm{s}$ & 1.198 & $<0.001$ & - & $<0.001$ \\
$\mathrm{D}, \mathrm{m} / \mathrm{s}$ & -0.315 & 0.500 & 27.72 & - \\
Density, $\mathrm{kg} / \mathrm{m}^{3}$ & 27.68 & $<0.001$ & 239.4 & $<0.001$ \\
Moisture content, $\%$ & 207.3 & 0.045 & & 0.0003 \\
\hline
\end{tabular}

Table 5. Predicting bending strength $(\mathrm{y})$ with different variables $(\mathrm{x})$ individually

\begin{tabular}{llrr}
\hline \multicolumn{1}{c}{ Variable $(\mathrm{x})$} & Regression equation & $\mathrm{R}^{2}$ & $\mathrm{p}$-value \\
\hline $\mathrm{A}, \mathrm{m} / \mathrm{s}$ & $\mathrm{y}=37.89+0.002{ }^{*} \mathrm{x}$ & 0.013 & 0.268 \\
$\mathrm{~B}, \mathrm{~m} / \mathrm{s}$ & $\mathrm{y}=31.75+0.004{ }^{*} \mathrm{x}$ & 0.062 & 0.016 \\
$\mathrm{C}, \mathrm{m} / \mathrm{s}$ & $\mathrm{y}=-14.35+0.01 *^{\mathrm{x}}$ & 0.178 & $<0.001$ \\
$\mathrm{D}, \mathrm{m} / \mathrm{s}$ & $\mathrm{y}=61.96+(-0.009)^{*} \mathrm{x}$ & 0.065 & 0.014 \\
Density, $\mathrm{kg} / \mathrm{m}^{3}$ & $\mathrm{y}=-15.11+0.131{ }^{*} \mathrm{x}$ & 0.261 & $<0.001$ \\
Moisture content, $\%$ & $\mathrm{y}=21.32+2.447{ }^{\mathrm{x}}$ & 0.096 & 0.003 \\
\hline
\end{tabular}


Table 6. Predicting bending strength (y) with multiple variables (x)

\begin{tabular}{lcccc}
\hline & $\begin{array}{c}\text { Regression equation with 6 variables } \\
\left(\mathrm{R}^{2}=0.413\right)\end{array}$ & \multicolumn{2}{c}{$\begin{array}{c}\text { Regression equation with } 4 \text { variables } \\
\left(\mathrm{R}^{2}=0.397\right)\end{array}$} \\
\cline { 2 - 5 } \multicolumn{1}{c}{ Variable } & regression - coefficient & $\mathrm{p}$-value & regression - coefficient & $\mathrm{p}$-value \\
\hline $\mathrm{A}, \mathrm{m} / \mathrm{s}$ & 0.001 & 0.461 & - & - \\
$\mathrm{B}, \mathrm{m} / \mathrm{s}$ & 0.002 & 0.285 & 0.003 & 0.044 \\
$\mathrm{C}, \mathrm{m} / \mathrm{s}$ & 0.005 & 0.040 & 0.005 & 0.033 \\
$\mathrm{D}, \mathrm{m} / \mathrm{s}$ & 0.006 & 0.259 & - & - \\
Density, $\mathrm{kg} / \mathrm{m}^{3}$ & 0.108 & $<0.001$ & 0.097 & $<0.001$ \\
Moisture content, $\%$ & 2.980 & 0.007 & 1.871 & 0.006 \\
\hline
\end{tabular}

Similar multiple regression analysis with all six variables was conducted. It shows (Table 6) that this model accounts for $41.3 \%$ of the variety of bending strength. Later, variables A and D (where p-values were greater than 0.05 ) were eliminated one by one, because their influence in the multiple regression analysis was not statistically significant.

The result is a regression equation with four variables that describe $39.7 \%$ of the variety of bending strength. The prediction equation $\left(\mathrm{R}^{2}=0.397\right.$ and $\mathrm{p}<0.001)$ is as follows:

$\sigma=-52.29+0.003 \cdot B+0.005 \cdot C+0.097 \cdot \rho+1.871 \cdot W$,

where: $\sigma$ is the bending strength, $\mathrm{MPa} ; B$ and $C$ are corresponding measuring techniques, $\mathrm{m} / \mathrm{s} ; \rho$ is density, $\mathrm{kg} / \mathrm{m}^{3}$ and $W$ is moisture content, $\%$.

\section{Conclusions}

The main aim was to investigate the possibilities of applying ultrasound measurement in assessment of the physical-mechanical properties of wood. For achieving this purpose a commercial device with $54 \mathrm{kHz}$ transducers was used to measure the ultrasound velocity in the timber samples sawn from logs and beams obtained from existing buildings. The total number of samples was 92 .

The analyses among the different measurement techniques showed that the shorter the measuring distance is, the more local is the evaluation for the sample. It turned out that the best arguments for predicting physicalmechanical properties were provided by the longitudinal (C) and indirect measurements with a distance of $600 \mathrm{~mm}$ (B), in good agreement with previous experimental observations.

The prediction equations with the main parameters of strength, like modulus of elasticity and bending strength, were found using variables of density, moisture content and four different ultrasound measuring methods. As a result of data analysis, a prediction equation for the modulus of elasticity accounting for about $80 \%$ of its variability was obtained, using the variables of density, moisture content, indirect measurement $\mathrm{B}$ and direct measurement C. Methods A and D were excluded. The other equation of predicting the bending strength had the percentage likelihood of about $40 \%$ and the same variables were excluded as before.

Thus it can be concluded that within those parameters it is possible to predict the modulus of elasticity and bending strength of a timber element with an accuracy of
$80 \%$ and $40 \%$, respectively. The other methods of measuring ultrasound velocity over smaller measuring distances gives only so-called local results of specimens, therefore they do not give assessment on a larger scale and they are not statistically significant. Thus the larger the measuring distance, the better the dependent variable can be predicted.

The assessment of strength of the samples by these methods will always be somewhat imprecise, because of imperfection of the results of measuring on site and not using standardised samples. Also it is necessary to note that in practice it is not possible to measure ultrasound velocities in the longitudinal direction.

Therefore more research in this field is needed, especially in the search for stronger relationships between acoustic properties obtained from indirect methods and mechanical strength values. Although the field of acoustics is a rather young one, this research clearly shows the potential of evaluating in situ wood structures with this kind of non-destructive method.

\section{References}

Arriaga, F.; Íñiguez, G.; Esteban, M.; Fernández-Golfín, J. I. 2006. Structural Tali timber (Erythrophleum ivorense A. Chev., Erythrophleum suaveolens Brenan.): Assessment of strength and stiffness properties using visual and ultrasonic methods, Holz als Roh- und Werkstoff 64(5): 357362. http://dx.doi.org/10.1007/s00107-006-0100-5

ASTM 494-89 Standard practice measuring velocity in materials. American Society for Testing and Materials (ASTM), USA, 1989. $34 \mathrm{p}$.

Bucur, V. 2006. Acoustics of Wood. 2nd Ed. Germany: Springer-Verlag. 393 p.

Bucur, V.; Chivers, R. C. 1991. Acoustic properties and anisotropy of some Australian wood species, Acta Acustica united with Acustica 75(1): 69-74.

Drdácký, M. F.; Kloiber, M. 2006. Non-destructive survey of historic timber, in Proc. of In-Situ Evaluation \& Nondestructive Testing of Historic Wood and Masonry Structures, Ed. by L. Binda, M. Drdácký, B. Kasal. Czech Republic, 2006, 8-23.

EN 408:2005 Timber structures - Structural timber and glued laminated timber - Determination of some physical and mechanical properties. European Committee for Standardization. Brussels, 2005. 34 p.

Hahnijärvi, A.; Ranta-Manus, A.; Turk, G. 2005. Potential of strength grading of timber with combined measurement techniques. Espoo, Finland. 81 p.

Haines, D. W.; Leban, J.-M.; Herbé, C. 1996. Determination of Young's modulus for spruce, fir and isotropic materials 
by resonance flexure method with comparison to static flexure and other dynamic methods, Wood Science and Technology 30(4): 253-263.

http://dx.doi.org/10.1007/BF00229348

ISO 3130:1975 Wood - Determination of moisture content for physical and mechanical tests. International Organization for Standardization. Switzerland, 1975. 2 p.

ISO 3131:1975 Wood - Determination of density for physical and mechanical tests. International Organization for Standardization. Switzerland, 1975. 2 p.

Kettunen, O. P. 2006. Wood structure and properties. Switzerland: Trans Tech Publications Ltd. 401 p.

Kotlinova, M.; Kloiber, M.; Vasconcelos, G.; Lourenco, P. J. B. B.; Branco, J. M. G. 2008. Non-destructive testing of wood. Portugal. $40 \mathrm{p}$.

Lempriere, B. M. 2002. Ultrasound and elastic waves. USA: Academic Press. 241 p.

Machado, J.; Palma, P.; Simoes, S. 2009. Ultrasound indirect method for evaluating clear wood strength and stiffness, in CD-Proceedings of the 7th International Symposium on Nondestructive Testing in Civil Engineering, 30 June 3 July, 2009, Nantes, France.

Mishiro, A. 1996. Effect of density on ultrasound velocity in wood, Mokuzai Gakkaishi 42(9): 887-894.
Niemz, P. 2009. Methods of non-destructive wood testing [Online], in Proc. of the International Conference of COST Action IE0601/ESWM [cited 15 September 2010]. Available from Internet: http://www.woodculther.com/ wp-content/uploads/2008/10/niemz1.pdf

Oliveira, F. G. R.; Candian, M.; Lucchette, F. F.; Salgon, J. L.; Sales, A. 2005. Moisture content effect on ultrasound velocity in Goupia Glabra, Materials Research 8(1): 11-14. http://dx.doi.org/10.1590/S1516-14392005000100004

Sakai, H. A.; Minamisawa, A.; Takagi, K. 1990. Effect of moisture content on ultrasonic velocity and attenuation in woods, Ultrasonics 28(6): 382-385. http://dx.doi.org/10.1016/0041-624X(90)90060-2

Sanabria, S. J.; Furrer, R.; Neuenschwander, J.; Niemz, P.; Sennhauser, U. 2011. Air-coupled ultrasound inspection of glued laminated timber, Holzforschung 65(3): 377-387. http://dx.doi.org/10.1515/hf.2011.050

Tanasoiu, V.; Miclea, C.; Tanasoiu, C. 2002. Non-destructive testing techniques and piezoelectric ultrasounds transducers for wood and built in wooden structures, Journal of Optoelectronics and Advanced Materials 4(4): 949-957.

Tico User Manual. 2008. Proceq SA, Schwerzenbach, Switzerland. $20 \mathrm{p}$.

Marko TEDER. PhD student, Institute of Forestry and Rural Engineering, Estonian University of Life Sciences. Research interests: assessment of timber structures, investigation of physical-mechanical properties of timber using nondestructive methods.

Kalle PILT. PhD student, lecturer, Institute of Forestry and Rural Engineering, Estonian University of Life Sciences. Research interests: relationships between basiomycete wood-rotting fungi Serpula lacrymans and Coniophora puteana biodeterioration rate and timber age.

Matis MILJAN. PhD student, specialist, Institute of Forestry and Rural Engineering, Estonian University of Life Sciences. Research interests: durability of timber structures, non-destructive methods, ecological and sustainable building.

Vello PALLAV. PhD student, lecturer, Institute of Forestry and Rural Engineering, Estonian University of Life Sciences. Research interests: reconstruction and renovation of buildings founded on weak soils.

Jaan MILJAN. Professor, Institute of Forestry and Rural Engineering, Estonian University of Life Sciences. Research interests: durability of building structures, ecological and sustainable building. 